\title{
The Analysis of Nascent Entrepreneurs' Happiness Level in Indonesia
}

\author{
Yosep Oktavianus Sitohang ${ }^{1} \bowtie$, Yoga Sasmita ${ }^{1}$, Yudhie Andriyana ${ }^{1}$, Gandhi Pawitan ${ }^{2}$, \\ ${ }^{1}$ Department of Statistics, Padjadjaran University, Bandung, Indonesia \\ ${ }^{2}$ Department of Business Administration, Katolik Parahyangan University, Bandung, Indonesia
}

\section{Info Article}

History Article:

Received August 2017

Approved August 2017

Published September 2017

\section{Keywords:}

Level of happiness; Motivation;

Perception; Innovation;

Demographic Variables.

\begin{abstract}
This study tried to analyze the factors that influence the happiness level of entrepreneurs in Indonesia especially the nascent entrepreneurs. The level of entrepreneurs' happiness has a positive effect on the sustainability of their business. The research data are secondary data from 1,148 respondents who are included in the category of Total Early-stage Entrepreneurial Activity (TEA) at Global Entrepreneurship Monitor (GEM) in 2013. The variables employed are motivation, perception and innovation and demographic variables (gender, education and income). Analyzer used is multiple linear regressions with dummy variable. From the result, it is found that only the motivation, education level and level of income that significantly influence the level of happiness. The nascent entrepreneurs, who have motivation to start a business because of opportunity, have a higher level of happiness than necessity motivation due to necessity. The level of education and income are also proportional to the level of happiness, but the level of education gives greater influence to the level of happiness of nascent entrepreneurs in Indonesia.
\end{abstract}

\section{Analisa Tingkat Kebahagiaan Pengusaha Baru di Indonesia}

\begin{abstract}
Abstrak
Penelitian ini mencoba menganalisa faktor-faktor yang mempengaruhi tingkat kebahagiaan pengusaha di Indonesia khususnya pengusaha baru. Tingkat kebahagiaan pengusaha berpengaruh positif terhadap keberlanjutan usahanya. Data penelitian berupa data sekunder yang berasal dari 1.148 responden yang termasuk dalam kategori Total Earlystage Entrepreneurial Activity (TEA) pada Global Entrepreneurship Monitor (GEM) tahun 2013. Variabel yang digunakan adalah motivasi, persepsi dan inovasi serta variabel demografi ( jenis kelamin, pendidikan dan pendapatan). Alat analisis yang dipakai adalah regresi linier berganda dengan variabel dummy. Dari hasil penelitian didapat bahwa hanya variabel motivasi, tingkat pendidikan dan tingkat pendapatan yang berpengaruh secara signifikan terhadap tingkat kebahagiaan. Pengusaha baru yang memiliki motivasi memulai usaha karena kesempatan, memiliki tingkat kebahagiaan yang lebih tinggi dibandingkan motivasi karena kebutuhan. Tingkat pendidikan dan tingkat pendapatan juga berbanding lurus kepada tingkat kebahagiaan, namun tingkat pendidikan memberikan pengaruh yang lebih besar terhadap tingkat kebahagiaan pengusaha baru di Indonesia.
\end{abstract}

JEL Classification: J1, J17

How to Cite: Sitohang, Y. O., Sasmita, Y., Andriyana, Y \& Pawitan, G. 2017. The Analysis of Nascent Entrepreneurs' Happiness Level in Indonesia. Jurnal Dinamika Manajemen. 8 (2): 259-268.

\begin{tabular}{lr}
\hline${ }^{\top}$ Correspondence Address & ISSN \\
Jalan Dipati Ukur 35 Bandung, Indonesia & $2086-0668$ (print) 2337-5434 (online) \\
E-mail: yosep1707@gmail.com & DOI: 10.15294/jdm.v8i2.12765
\end{tabular}




\section{INTRODUCTION}

Improving the quality of human life and the people of Indonesia is one of the nine priority agendas (NAWACITA) initiated by the government of President Joko Widodo. Increasing the level of welfare of the Indonesian people should be enjoyed in the realm of independence that has lasted more than half a century. One measure of the program's success is the declining unemployment rate.

By 2015, the unemployment rate in Indonesia reaches $6.18 \%$ (BPS, 2015). This figure increases when compared with the previous year. The growing number of workers each year but not accompanied by the addition of employment is one of the causes of the increase in the unemployment rate. One way to reduce unemployment is to improve entrepreneurship (Hendro, 2011).

Entrepreneurs are people who have the ability to see and assess business opportunities, gather the resources needed to take advantage of them and take appropriate action, to ensure success (Meredith et al., 1982). According to Mas'ud and Mahmud (2004) entrepreneurs are creative and innovative people and always develop themselves for new discoveries. Therefore entrepreneurs can assist the government in creating new jobs and contribute to the national economy. According to Charron et al. (2012) entrepreneurship is an important stimulus to economic growth. Hence, the accurate information on entrepreneurship is needed by the government as the basis for policy making.

The Global Entrepreneurship Monitor (GEM) study is a study that measures entrepreneurship in 104 state economies and has gained wide acclaim as a powerful, longitudinal entrepreneurial research in the world (Nawangpalupi et al., 2014). GEM provides a comprehensive view of entrepreneurship globally by looking at the attitudes of a population and the activities and characteristics of the individuals involved. GEM research records entrepreneurship as a process consisting of different phases, starting from the intention to establish a business, run a business that has stood, until the cessation of a business.

The GEM research conducted in Indonesia sampled 4,500 adults (18-64 years old) from urban and rural areas around the provincial capital. A total of 16 provinces were selected as a sample with the consideration that the 16 provinces represent almost $85 \%$ of the Indonesian population. Based on data published by GEM in 2013, Indonesia is the country with the highest new business ownership rate in Southeast Asia. This is in line with the percentage of Total Earlystage Entrepreneurial Activity (TEA) of 25.5\%. The TEA measures the percentage of the 18-64 year population that is a nascent entrepreneur.

The interesting thing about GEM research is about the sustainability of entrepreneurial activities. The results showed that the ratio of entrepreneurs in Indonesia who stopped the business is very small, i.e. only $2.4 \%$ of all entrepreneurs. These data indicate that the commitment of entrepreneurs to continue to pursue and maintain the sustainability of their business is quite high. This is in line with the results of research Parasuraman et al. (1996) which states that the variables affecting the success of an entrepreneur are his commitment to the job. One of the factors that determine the commitment is the quality of life/ well-being of the entrepreneur.

The benchmark oftentimes used in measuring quality of life/ wellbeing is the level of income. Not only are benchmarks limited to the level of income received because it can only capture the level of welfare in the short term. According to Ryff and Singer (2008) an individual can be said to be prosperous when the individual is able to accept his present life, has a positive relationship with many people, has the ability to deal with pressure and self-direction, able to set goals and direction in life as well as in self and develops sustainably and ultimately the ability to own and create an environment that suits his or her physical condition.

Psychological well-being is a multidimensional measure of psychological development and mental health, including the scale of the 
Yosep Oktavianus Sitohang, et al. / The Analysis of Nascent Entrepreneurs' Happiness...

degree of independence and positive relationships with others that can also be expressed in happiness.

Happiness refers to how a person experiences the quality of his life and in it there are emotional reactions and cognitive decisions. Under stressful circumstances, individuals with high levels of happiness will be better able to adapt so they can experience a good life. It makes happiness as one important factor that affects entrepreneurs in his business. Blanchflower (2004), Mahadea (2014), Mahadea and Ramroop (2015) found that there is a positive correlation between being a businessman with happiness, although it is not a strong correlation.

The study was also supported by Andersson (2008) who conducted the study using a level of living survey in Sweden from 1991-2000. $\mathrm{He}$ found that there was indeed a positive correlation between entrepreneurship and happiness. Binder and Coad (2012) also found that an employee who chose to be an entrepreneur had a positive and significant increase in his level of happiness, thus indicating that leaving a job and becoming an entrepreneur positively affects the level of one's happiness. Berglund (2014) also conducted research on happiness and job satisfaction (job satisfaction) to entrepreneurs in Sweden. The results found that employers have a higher level of happiness and job satisfaction than regular employees. This is also in line with Mahadea and Ramroop research results (2015). In addition, based on research Sherman et al. (2015) to entrepreneurs in the United States, the level of happiness also has a positive effect on work productivity.

Based on the existing literature, there are factors that significantly affect the happiness of the entrepreneur. According to Salinas-Jimenez et al. (2010) the happiness of entrepreneurs is influenced by motivation, whether internal or external. Internal motivation deals with the desire to achieve and relate to others. This can result in a higher level of happiness. But on the basis of the same research, external motivations measured by income and good security from work are negatively related to the level of hap- piness. Several other studies have found the motivation for entrepreneurship to be broadly divided into two aspects: opportunity and necessity (Reynolds et al., 2002, Bhola et al., 2006; Estay et al., 2013; Zali et al., 2013; Zimmerman \& Chu, 2013; Zbierowski, 2014).

From the results of research Saiz-Alvarez et al. (2014) and Naudé, et al. (2014) it was reported that entrepreneurs who started businesses with opportunity motivation had higher levels of happiness. The next factor affecting the level of happiness is innovation (Olcay \& Kunday, 2016). In line with the notion of entrepreneurs by Mas'ud and Mahmud (2004), which distinguishes employers from employees, is an emphasis on innovation. Innovation is one of the keys to the happiness of an entrepreneur.

This is also supported by research Hadiyati (2011) that innovation has a big effect on entrepreneurship. Furthermore, the perception that a person must have the skills, knowledge and experience to start a new business also has a positive relationship to the level of happiness of the entrepreneur. Based on GEM data, Indonesia's population has a high perception rate of 62\% (Nawangpalupi et al., 2014).

The wellbeing was a special topic raised by GEM in its research in 2013. The purpose of this topic is to measure whether quality of life is an entrepreneurial motivator, where some questions are asked regarding the level of happiness. The results of GEM research descriptively found that in Indonesia entrepreneurs have an average value of happiness that is almost the same as non-entrepreneurs. In addition, there is a similarity in the average value of happiness for TEA, both men and women and their motivation to start a business (motivation due to opportunity and necessity).

Based on the above matters, the authors try to analyse whether perception, innovation and motivation really give a significant influence to the happiness level of entrepreneurs in Indonesia especially nascent entrepreneurs. In addition it refers to the research of Liao (2009), Olcay and Kunday (2016) the authors also want to see whether gender, education level and in- 
come level, also have a significant effect on the level of happiness of nascent entrepreneurs in Indonesia.

\section{Hypothesis Development}

Referring to Salinas-Jimenez et al. (2010) which shows that employers' motivation affects their level of happiness, as well as research by Reynolds et al. (2002) who said that the motivation can consist of two things, namely because of opportunity and necessity, so the first Hypothesis raised is:

H1: Do nascent entrepreneurs having the motivation to start a business due to the opportunity have higher happiness rate than the entrepreneurs who started the business due to the necessity?

In addition, based on the study of Olcay and Kunday (2016) and Liao (2009) which is indicating that the level of happiness entrepreneurs are also influenced by perceptions, innovations and demographic variables such as gender, education and income then the next Hypothesis that is built is:

H2: Do nascent entrepreneurs who have the perception that the entrepreneurs must have the skills, knowledge and experience to start a new business have an influence on the level of them happiness?

H3: Do nascent entrepreneurs with high innovation have an influence on them level of happiness?
H4: Do gender variables have an effect on the level of happiness of nascent entrepreneurs?

H5: Do the income level variables have an effect on the level of happiness of nascent entrepreneurs?

H6: Do the educational level variables have an influence on the level of happiness of nascent entrepreneurs?

\section{METHOD}

The data used are from GEM secondary data in 2013 for Indonesia. This study focuses on nascent entrepreneurs who have been actively involved in the arrangement of a business owned or shared property but have not paid wages, salary or other payment to the owner for less than 3 months or those who own or manage a business and have paid wages, salary or other payment to the owner within 3 to 42 months, where in GEM this concept is known as TEA (Early-stage Entrepreneurial Activity). Therefore, from 4,500 GEM respondents, there are only selected 1,148 respondents only, which meet the above criteria. The variables used are formed from the question items contained in the GEM questionnaire (Table 1).

The information on the GEM questionnaire and the data used in this study were obtained through online access at http://www. gemconsortium.org website. Because there are free variables of nominal and ordinal sca-

Tabel 1. The Employed Research Variables and Question Items of GEM Questionnaire

\begin{tabular}{ll}
\hline \multicolumn{1}{c}{ Variables } & \multicolumn{1}{c}{ Items (questionnaire item codes) } \\
\hline Happiness Level & In most ways my life is close to my ideal (WLIDL) \\
The conditions of my life are excellent (WLEXL) & I am satisfied with my life (WLSLF) \\
So far I have obtained the important things I want in life (WLIMP) \\
If I could live my life again, I would not change anything (WLCHN) \\
The answer scale of the five items above is from the number 1 to 5. The \\
value of the happiness rate is the average of the five values of the answer.
\end{tabular}


Yosep Oktavianus Sitohang, et al. / The Analysis of Nascent Entrepreneurs' Happiness...

Tabel 1. Continuous

\begin{tabular}{|c|c|}
\hline Variables & Items (questionnaire item codes) \\
\hline Motivation & $\begin{array}{l}\text { Are you involved in this start-up to take advantage of a business oppor- } \\
\text { tunity or because you have no better choices for work? (SUREASON) } \\
\text { For a choice of answers as no other job option is better considered as } \\
\text { motivation because the necessity and choice of answers for wanting to } \\
\text { take advantage of a business opportunity is considered as motivation due } \\
\text { to the opportunity. The scale of this variable consists of } 2 \text { namely } 0 \text { is for } \\
\text { motivation due to necessity and } 1 \text { is for motivation due to opportunity }\end{array}$ \\
\hline Perception & $\begin{array}{l}\text { Do you have the knowledge, skills and experience required to start a new } \\
\text { business? (SUSKILL) } \\
\text { The scale of this variable is } 0 \text { for no and } 1 \text { for yes }\end{array}$ \\
\hline Innovation & $\begin{array}{l}\text { Will all, some, or none of your potential customers consider this product } \\
\text { or service new and unfamiliar? (SUNEWCST) } \\
\text { Right now, are there many, few, or no other businesses offering the same } \\
\text { products or services to your potential customers? (SUNCOMPET) } \\
\text { How long have the technologies or procedures required for this product } \\
\text { or service been available? (SUNEWTEC) } \\
\text { The answer scale of the three items above is 1-3. The value of this variable } \\
\text { is the average of the values of the three items above. }\end{array}$ \\
\hline Gender & The scale of this variable is 0 for males and 1 for females (GENDER) \\
\hline Education Level & $\begin{array}{l}\text { This variable is divided into } 3 \text { answer scales (IDREDUC): } \\
\text { Scale } 0 \text { is for Basic Education (SMP, SD, including those who have never } \\
\text { attended school or who did not finish primary school) } \\
\text { Scale } 1 \text { is for secondary education (high school or equivalent) } \\
\text { Scale } 2 \text { is for higher education (diploma and graduate) }\end{array}$ \\
\hline Income Level & $\begin{array}{l}\text { Income is divided into } 3 \text { answer scales (GEMHHINC): } \\
\text { Scale } 1 \text { is for low income groups } \\
\text { Scale } 2 \text { is for average income groups } \\
\text { Scale } 3 \text { is for high income groups }\end{array}$ \\
\hline
\end{tabular}

le then the analysis tool used is Multiple Linear Regression with dummy variable (Jerry, 1974).

Dummy variable is a categorical variable that is suspected to have an influence on the dependent variable that is continuous. Besides, this research only aims to see the effect of independent variables on response variable, therefore used regression analysis with standardized regression coefficient. The model in this research is:

$$
\mathrm{Y}=\mathrm{aX} 1+\mathrm{bX} 2+\mathrm{cX} 3+\mathrm{dX} 4+\mathrm{eX} 5+\mathrm{fX} 6
$$

Where:

$\mathrm{Y}=$ The Level of Happiness

$\mathrm{X} 1$ = Motivation (Dummy Variable 1$)$

$\mathrm{X} 2$ = Perception (Dummy Variable 2)

$\mathrm{X} 3$ = Innovation

X4 $=$ Gender (Dummy Variable 3)

X5 = Income Level (Dummy Variable 4)

X6 = Education Level (Dummy Variable 5)

$a, b, c, d, e, f=$ Parameters 


\section{RESULT AND DISCUSSION}

Based on GEM data, it is known that descriptively TEA who start a business with opportunity motivation have a value of involvement of $44 \%$ while those who start a business with necessity motivation only worth $25 \%$. This indicates that nascent entrepreneurs in indonesia mostly see an opportunity that their future will change better if they become entrepreneurs. In addition, when viewed by sex, the proportion of male and female TEA have almost the same value. The data shows that in indonesia both men and women have equal opportunity to become entrepreneurs.

The perception that the entrepreneur must have the skills, knowledge and experience to start a business is a positive suggestion to achieve success in the business. According to the GEM data, the number of nascent entrepreneurs who believe in the perception reached $62 \%$. This optimism is in line with the commitment of entrepreneurs to continue to pursue and maintain the sustainability of their business, as proved by the ratio of entrepreneurs in indonesia who stopped the business that is only $2.4 \%$ of all entrepreneurs (Nawangpalupi et al., 2014).

Furthermore, when viewed from the income level, only about $16 \%$ of nascent entrepreneurs who have high income levels, while the rest are at the level of income around and below the average. This is because in the early stages of pioneering the business, financial and marketing conditions of the business is still not stable. However, when the entrepreneurs get past this early stage, the chances of achieving success rises. The results descriptive of perception and income level can be seen in Figure 1.

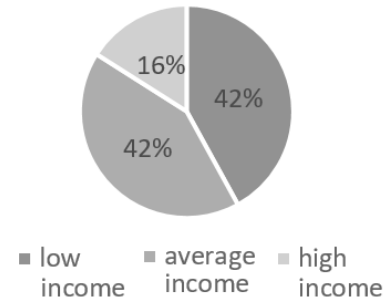

(a)

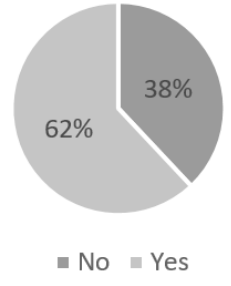

(b)
Figure 1: The Presentage of Nascent Entrepreneurs Based on (a) Perception and (b) Income Level
The information on the current level of educational attainment is the best available indicator to look at the skill level of the workforce (BPS, 2015), including entrepreneurs. The level of expertise is one of the determinants of entrepreneurs to compete successfully in the business. Based on the calculation results obtained, $53.3 \%$ of nascent entrepreneurs have secondary education level, while $35.9 \%$ have basic education down and only $10.8 \%$ have diploma and undergraduate education. This descriptive result is expected that the entrepreneurs have a good competitiveness because it already has a provision of high. However, when compared with other ASEAN countries, the level of expertise of Indonesian workers is still quite low. This is because the proportion of highly educated entrepreneurs in other ASEAN countries is quite a lot.

Furthermore, the Hypothesis raised in this study will be tested using an analysis tool that is Multiple Linear Regression with dummy variables. The results of processing using IBM SPSS software version 20 obtained results that can be seen in Table 2 .

Tabel 2. Estimasi Parameter Model (1)

\begin{tabular}{lcc}
\hline \multicolumn{1}{c}{ Details } & Coefficients & t-Stat $(\mathbf{p}$-Value $)$ \\
\cline { 2 - 3 } Motivation & 0.170 & $3.436(0.001)$ \\
Perception & 0.041 & $0.825(0.410)$ \\
Innovation & 0.087 & $1.759(0.079)$ \\
Gender & -0.015 & $-0.300(0.764)$ \\
Income Level & 0.112 & $2.225(0.027)$ \\
Education Level & 0.155 & $3.117(0.002)$ \\
\hline ANOVA $(p$-value $)$ & 0.000 & \\
\hline
\end{tabular}

Based on the above data, with alpha 5\% through ANOVA testing it is found that overall, independent variables have an influence on the dependent variable. However, after a partial test by referring $p$-value values of each variable, it was found that the variables of perception, innovation and gender did not have a significant influence on the dependent variable (level of happiness). Variables of perception and innovation that have no effect on the level of happiness 
Yosep Oktavianus Sitohang, et al. / The Analysis of Nascent Entrepreneurs' Happiness...

give results that are slightly different from previous studies (Hadiyanti, 2011; Olcay \& Kunday, 2016).

An early indication for answering the phenomenon is that both variables do contribute directly to the success of the entrepreneur but not directly to the level of happiness of the entrepreneur. Furthermore, the insignificance of gender variables on the quality of life of entrepreneurs is also supported by some literature which states that male and female entrepreneurs have the same happiness in their lives and in work (Cooper \& Artz, 1995; Saiz-Alvarez et al. 2011; Carree \& Verheul, 2012).

Moreover, reprocessing is done by removing the three insignificant variables, so that the results obtained in Table 3 .

Tabel 3. Estimasi Parameter Model (2)

\begin{tabular}{lcc}
\hline \multicolumn{1}{c}{ Details } & Coefficients & t-Stat (p-Value) \\
\hline Motivation & 0.157 & $3.257(0.001)$ \\
Income Level & 0.114 & $2.367(0.018)$ \\
Education Level & 0.119 & $2.456(0.014)$ \\
\hline ANOVA $(p$-value $)$ & 0.000 & \\
\hline
\end{tabular}

Based on Table 3 it is seen that all the variables used have significant influence, seen from the test result either partially or as a whole. When we will compare the level happiness of nascent entrepreneurs who have the motivation to start a business because of the chance with nascent entrepreneurs who start the business due to the necessity, then we change the value of $\mathrm{X} 1$ with the value of scale, where the value 0 is for motivation because the necessity and value 1 is for motivation because the opportunity, assuming other variables is considered constant. The result is the level of happiness of nascent entrepreneurs who started the business because the motivation of opportunity is higher than the one who started the business because of the motivation of necessity. This answers the Hypothesis $\mathrm{H} 1$.

This result can give an answer to $\mathrm{H} 2$ and $\mathrm{H} 3$ research Hypothesis that perception and innovation cannot be said to have significant effect to the happiness level of new entrepreneurs in Indonesia, as well as to Hypothesis of $\mathrm{H} 4$ research that there is no significant difference between male and female nascent entrepreneurs in terms of the level of happiness.

In the same way as above, we will look at the role of variable income level and level of education. Increasing the level of income and education level of new entrepreneurs in Indonesia will increase the level of happiness. This condition is quite in line with the happiness index of the Indonesian population released by BPS (2017). The happiness index is one of the indicators used to measure community welfare based on the level of community happiness. According to the BPS publication, the higher the income level and education level of a person is, the higher the happiness index will be. This result is also in harmony with the results of research on the level of happiness entrepreneurs undertaken by $\mathrm{Uy}$ et al. (2013), where the higher level of income or education level of entrepreneurs then the higher the level of happiness will be. The above results answer from Hypothesis $\mathrm{H} 5$ and $\mathrm{H} 6$.

Furthermore, when making the variable level of education and income level as a control variable to the relationship of variables motivation to the level of happiness of nascent entrepreneurs, it is found that nascent entrepreneurs who start the business because of opportunity motivation or necessity motivation, with a certain level of income, have a higher level of happiness than entrepreneurs with the same motivation but have lower income levels. The same phenomenon also occurs in the control variables of education level.

This shows that regardless of the motivation of nascent entrepreneurs to enter into entrepreneurship, the level of income earned and the level of education held is an important factor that determines the level of happiness. However, if the influence of these two variables is compared, then the level of education gives more influence than the level of income. in other words, the nascent entrepreneurs in Indonesia see the level of education that he currently has more im- 
portantly affects his level of happiness than the amount of income received today. This condition can be explained because the current high level of income cannot guarantee the success of the business in the future, while the high level of education will increase the chances of success in the future which will eventually increase revenue (Robinson \& Sexton, 2012).

\section{CONCLUSIONAND RECOMMENDATION}

The level of happiness becomes one of the factors that determine the sustainability of the business of an entrepreneur. Therefore, happiness is an interesting thing to study, because it can provide comprehensive input to the stakeholders in making the right decision for the sustainability of entrepreneurship in indonesia. This study tries to analyse the factors that affect the happiness level of entrepreneurs in indonesia, especially nascent entrepreneurs. From the result of the research, it is found the perception that the entrepreneur must have the skills, knowledge and experience to start a business has no effect to the level of happiness of nascent entrepreneurs. It goes also for innovation and gender variables.

However, for the motivation variable, the income level and the level of education, give a significant influence to the happiness level of the nascent entrepreneurs. There are two interesting things found in this research. First, nascent entrepreneurs who start businesses because the opportunity has a higher happiness rate than nascent entrepreneurs who start the business because of necessity motivation. In this case the government should be more vigorous in educating the public to have a motivation in starting a business not just because of limited options but also because of the opportunity.

Second is that the level of education and income levels also have a positive effect on the level of happiness, but the level of education has a greater influence when compared with the level of income. This shows that the nascent entrepreneurs in indonesia consider the level of education can increase the chances of success in the business that ultimately can increase revenue. The level of education here also includes the level of expertise that entrepreneurs have. Therefore, the government needs to intensify the training to the entrepreneurs, especially to nascent entrepreneurs in order to increase their skills so that they can compete in the business. By paying attention to these two things, it is expected that the business continuity of entrepreneurs can be maintained and even able to absorb labour so that NAWACITA's goal from the government can be fulfilled, that is reducing unemployment.

The study has limitations which do not consider the economic, demographic and political conditions of Indonesia in the year in which GEM data was collected. This is important because it will certainly provide a more complete and accurate view. Further studies should consider this.

\section{Acknowledgment}

This research is supported by Statistics Indonesia (BPS) and Master Program of Applied Statistics, Padjadjaran University.

\section{REFERENCES}

Andersson, P. 2008. Happiness and Health: Wellbeing among the Self-Employed. The Journal of Socio-Economics. 37: 213-236.

Badan Pusat Statistik. 2015. Indikator Pasar Tenaga Kerja Indonesia Agustus 2015. Jakarta: BPS.

Badan Pusat Statistik. 2017. Laporan Bulanan Data Sosial Ekonomi September 2017. Jakarta: BPS.

Berglund, V. 2014. Entrepreneurs Subjective Wellbeing and Job Satisfaction: does Personality Matter?. Sociologiska Institutionen UMEA Universitet. 40: 1-25.

Bhola, R., Verheul, I., Thurik, A. R \& Grilo, I. 2006. Explaining EngagementLevels of Opportunity and Necessity Entrepreneurs. Business \& Policy Research. 1-45.

Binder, M \& Coad, A. 2012. Life Satisfaction and Self-Employment: a Matching Approach. 
Yosep Oktavianus Sitohang, et al. / The Analysis of Nascent Entrepreneurs' Happiness...

Small Business Economics. 40 (4): 10091033.

Blanchflower, D. 2004. Self-Employed: More May Not Be Better. Swedish Economic Policy Review. 11 (2): 15-73.

Cakar, N. D \& Erturk, A. 2010. Comparing Innovation Capability of Small and Medium-Sized Enterprises: Examining the Effects of Organizational Culture and Empowerment. Journal of Small Business Management. 48 (3): 325-359.

Carree, M \& Verheul, I. 2012. What Makes Entrepreneurs Happy? Determinants of Satisfaction among Founders. Journal of Happiness Studies. 13 (2): 371-387.

Charron, N., Lapuente, V \& Nistotskaya, M. 2012. The Wealth of Regions: Government Quality and Entrepreneurship in Europe. European Quality of Government Index Working Paper Series. University of Guthenburg. 2012:12.

Estay C., Durrieu, F \& Akhter, M. 2013. Entrepreneurship: from Motivation to Start-up. Journal of International Entrepreneurship. 11 (3): 243-267.

Jerry L., Miller, L \& Erickson, M. L. 1974. On Dummy Variable Regression Analysis. Sociological Methods \& Research. 2 (4): 409-430.

Landstrom, H., Harirchi, G \& Astrom, F. 2012. Entrepreneurship: Exploring the Knowledge Base. Research Policy Journal. 41 (7): 11541181.

Liao, P. 2009. Parallels Between Objective Indicators and Subjective Perceptions of Quality of Life: A Study of Metropolitan and County Areas in Taiwan. Social Indicators Resesarch. 91 (1): 99-114.

Mahadea, D. 2014. Happinomics among Factors of Production using a Principal Component Analysis Approach: A Case Study of Labour and Entrepreneurs' Subjective Happiness in KwaZulu-Natal, South Africa. Mediterranean Journal of Social Sciences. 5 (4): 99-110.

Mahadea, D \& Ramroop, S. 2015. Influences on Happiness and Subjective Well-being of Entrepreneurs and Labour: Kwazulu-Natal Case Study. South African Journal of Economic and Management Sciences. 18 (2):245-259.
Mulyana \& Sutapa. 2016. The Impact of Entrepreneurial Orientation and Collaborative Networks on Creative Industries Performance. Jurnal Dinamika Manajemen. 7 (2): 166-181.

Mahadea, D \& Ramroop, S. 2015. Influences on Happiness and Subjective Well-Being of Entrepreneurs and Labour: Kwazulu-Natal case study. South African Journal of Economic and Management Sciences. 18 (2): 245-259.

Naudé, W., Amorós, J. E \& Cristi, O. 2014. Surfeiting, the Appetite may Sicken: Entrepreneurship and Happiness. Small Business Economics. 42 (3): 523-540.

Nawangpalupi, C. B., Pawitan, G., Gunawan, A., Widyarin, M \& Iskandar, T. 2014. Global Entrepreneurship Monitor 2013 Indonesia Report. Bandung: Universitas Katolik Parahyangan.

Olcay, G \& Kunday, O. 2016. Determinants of Well-being of Turkish Entrepreneurs: an Assessment Based on Entrepreneurial Perception, Motives and Innovation. Journal of Entrepreneurship and Innovation Management. 5: 1-16.

Parasuraman, S., Purohit, Y. S \& Godshalk, V. M. 1996. Work and Family Variable, Entrepreneurial Career Success and Psychological Wellbeing. Journal of Vocational Behavior. 48 (3): 275-300.

Reynolds, P. D., Bygrave, W. D., Autio, E., Cox, L. W \& Hay, M. 2002. The Entrepreneur Next Door: Characteristics of Individuals Starting Companies in America: An Executive Summary of the Panel Study of Entrepreneurial Dynamics. 2002 Executive Report. SSRN University Ave.

Romero, I \& Martinez-Romain, J. A. 2012. SelfEmployment and Innovation. Exploring the Determinants of Innovative Behavior in Small Businesses. Research Policy Journal. 41 (1): 178-189.

Ryff, C. D \& Singer, H. B. 2008. Know Thyself and Become What You Are a Eudaimonic Approach to Psychological Wellbeing. Journal of Happiness Studies. 9: 13-39.

Saiz-Alvarez, J. M., Martinez, A. C \& Martinez, C. C. 2014. An Entrepreneurial Well-Being Model Based on GEM Data for Spain. Inter- 
national Journal of Artificial Intelligence and Interactive Multimedia. 2 (5): 38-47.

Salinas-Jimenez, M., Artes, J \& Salinas-Jimenez, J. 2010. Income, Motivation and Satisfaction with Life: An Empirical Analysis. Journal of Happiness Studies. 11 (6): 779-793.

Schaltegger, S \& Wagner, M. 2011. Sustainable Entrepreneurship and Sustainability Innovation: Categories and Interactions. Business Strategy and the Environment. 20 (4): 222-237.

Sherman, C. L., Randall, C \& Kauanui S. K. 2015. Are You Happy yet? Entrepreneurs' Subjective Well-being. Journal of Management, Spirituality \& Religion. 13 (1): 7-23.

Uy, M. A., Foo, M. D \& Song, Z. 2013. Joint Effects of Prior Start-Up Experience and Coping Strategies on Entrepreneurs' Psychological Well-Being. Journal of Business Venturing. 28 (5): 583-597.

Williams, C. C \& Nadin, S. 2010. Entrepreneurship and the Informal Economy: an Overview.
Journal of Developmental Entrepreneurship. 15 (4): 361-378.

Wynarczyk, P. 2013. Open Innovation in SMEs: a Dynamic Approach to Modern Entrepreneurship in the Twenty-First Century. Journal of Small Business and Enterprise Development. 20 (2): 258-278.

Zali, M. R., Faghih, N., Ghotbi, S \& Rajaie, S. 2013. The Effect of Necessity and Opportunity Driven Entrepreneurship on Business Growth. International Research Journal of Applied and Basic Sciences. 7 (2): 100108.

Zbierowski, P. 2014. Well-being of EntrepreneursInternational Comparison Based on GEM Data. Journal of Positive Management. 5 (4): 89-100.

Zimmerman, M. A \& Chu, H. M. 2013. Motivation, Success and Problems of Entrepreneurs in Venezuela. Journal of Management Policy and Practice. 14 (2): 76-90. 